\title{
TOPENG PAJEGAN SEBAGAI MEDIA PENERANGAN AGAMA HINDU
}

\author{
I Made Gde Puasa ${ }^{1}$ \\ Fakultas Dharma Duta, \\ Institut Hindu Dharma Negeri Denpasar
}

\begin{abstract}
Pajegan Mask is one of the many arts in Bali. Pajegan Mask Dance is a performance art which in its performance is a symbol of human life that talks about life and human behavior and character. The Pajegan Mask performance is motivated by the Pajegan Mask Performance as a guardian, bebali and balih-balihan whose roles still need to be improved as a medium for illuminating Hinduism.

Based on this, what will be discussed in this paper include: (1) The form of the Pajegan Mask Performance as a medium for illuminating Hinduism. (2) The function of the Pajegan Mask Performance functions as a medium for illuminating Hinduism. (3) The meaning contained in the Pajegan Mask Performance as a media for the illumination of Hindu religion.

Analiisis Pajegan Mask dance form shows the physical understanding of a work of art that functionally contains life characteristics related to religious rituals, while the form of Pajegan Mask Dance performance consists of: (1) The form of Pajegan Mask Dance performance, (2) the Pajegan Mask performance function, namely: (1) Communication and information media, (2) Entertainment media, (3) Social criticism function. The meanings of the Pajegan Mask are: (1) The religious and social meaning, (2) The spiritual meaning. So the Pajegan Mask Dance performance is not only used as a ritual complement in Hindu religious ceremonies, but its role really needs to be maximized and enhanced as a medium for illuminating Hinduism.
\end{abstract}

Keywords Pajegan Mask, Hindu Communication Media, Spiritual

\section{PENDAHULUAN}

Membahas sebuah karya seni atau kesenian, maka tidak dapat terlepaskan dari konteks kebudayaan yang melahirkan seni itu sendiri. Agama Hindu merupakan sumber karya seni di Bali yang dijadikan landasan untuk mendorong inspirasi dari segala karya

${ }^{1}$ madepuasa@gmail.com 
kreatif masyarakat Bali. Hubungan ini disebabkan oleh karena seni atau kesenian merupakan bagian dari tujuh unsur kebudayaan yang bersifat universal, artinya sekecil atau sesederhana apapun kebudayaan suatu suku bangsa unsur kesenian ada di dalamnya.

Setiap kebudayaan suku bangsa di dunia memiliki tujuh unsur kebudayaan yang disebut cultural universal, yaitu meliputi : (1) bahasa, (2) sistem pengetahuan, (3) organisasi sosial, (4) sistem peralatan hidup dan teknologi, (5) sistem mata pencaharian hidup, (6) sistem religi, dan (7) sistem kesenian (Koncaraningrat, 1990 :203-204). Untuk dapat mengerti, menyelami dan menilai usaha karya seni dari suatu bangsa dengan seksama, tidaklah hanya cukup menganalisa bentuk-bentuk karya seni saja, kesusastraannya, seni suaranya, taritariannya dan seni rupanya. Pemahaman terhadap gaya hidup, keyakinan kepercayaan dan struktur penghidupan dari suatu masyarakat adalah sendi- sendi yang sangat penting dalam penuangan bentuk karya seninya sehingga dianggap sangat perlu diselami dengan penuh simpati dan secara tertib untuk dapat mengadakan interprestasi dan peninjauan yang tepat (Murdowo 1967:18).

Bali salah satu dari suku bangsa di Indonesia memiliki karakteristik seni dan budaya yang menarik bagi wisatawan mancanegara untuk dikunjungi agar dapat melihat kepaduan estetika budaya yang diilhami oleh sebuah bingkai, yaitu Agama Hindu. Berdasarkan hal tersebut, Bali terkenal dengan berbagai julukan, seperti: Pulau Sorga, Paradise Island, Pulau seribu Pura, Pulau Pariwisata dan lain sebagainya.

Lestarinya berbagai kesenian di pulau Bali karena hubungan agama Hindu dengan seni tak dapat dipisahkan, hai itu dapat menumbuhkan rasa seni yang sangat mendalam bagi masyarakat dalam berbagai bidang, terutama dalam bidang seni pahat, seni gamelan, seni lukis, seni tari, seni hias dan lain-lain (Mantra, 1991:5).

Setiap orang di Bali seakan-akan seorang seniman, kuli, pangeran, pendeta, dan petani, baik laki-laki maupun perempuan, dapat menari, memainkan instrument musik, melukis atau memahat pada kayu dan batu. Kadang ditemukan dengan tidak sengaja, sebuah desa yang miskin dan hampir roboh memelihara sebuah Pura dengan sungguh-sungguh, memiliki seperangkat musik dan sekumpulan aktris ulung (Covarrubias, 1952:67).

Berdasarkan pemaparan seni kebudayaan dan agama tersebut di atas, seni pertunjukan keagamaan (sakral) yang termasuk salah satu seni pertunjukan (performiing art) yang sangat populer di kalangan masyarakat Bali memang berkaitan dengan aspek budaya dan agama. Seni pertunjukan adalah suatu 
aktivitas yang bisa dipersiapkan dengan masak dan dapat dipilih benar pesannya, pelakunya dan serta ditata dengan pertimbangan artistic. Adapun pelakunya adalah seniman pentas, pemusik, actor dan aktris (Murgianto, 1993:4).

Seni pertunjukan melibatkan banyak orang, seniman pelaku, pembantu, dan masyarakat penonton (Dibya, 1993:138). Seni pertunjukan merupakan suatu kegiatan yang bersifat kolektif pada masyarakat tertentu yang mampu memberikan kebahagiaan, memberikan makanan kepada rasa estetik setiap anggota masyarakat (Sedyawati, 1981:85).

Seni pertunjukan di Bali mengalami zaman keemasan sejak tahun 70-an, dimana seni pertunjukan di Bali cukup beragam mulai dari seni pertunjukan yang bersifat Seni Wali seperti : Sanghyang, Rejang. Seni Bebali yakni Gambuh, Wayang Wong, dan Seni Balih-Balihan yakni Legong, Arja, Kebyar (Bandem 1996:62). Selain itu perlu diketahui bahwa seni pertunjukan tradisional dalam kesenian Bali meliputi: Drama tari Gambuh, Wayang Kulit, Drama Tari Topeng dan Prembon, Calonarang, Opera tari Arja, Sendratari dan Drama Gong (Dibia, 1993:137).

Pementasan Topeng Pajegan dapat merupakan suatu usaha untuk melestarikan salah satu budaya bangsa yang memiliki nilai-nilai ajaran agama Hindu. Karena semua paralatan yang terkait dengan pementasan Topeng Pajegan mempunyai nilai-nilai simbol dalam kehidupan masyarakat Hindu. Sistem relegi merupakan salah satu dari unsur kebudayaan yang universal tersebut, disamping itu juga relegi merupakan salah satu dari unsur kebudayaan dari setiap suku atau bangsa di dunia. Membahas mengenai pementasan Topeng Pajegan di Bali, karena hubungan Agama Hindu tidak dapat lepas dari seni, maka dalam hai ini dapat menumbuhkan rasa yang sangat mendalam dalam masyarakat terutama bidang seni pahat, seni gambelan, seni lukis, seni tari, dan seni yang lainnya ( Mantra, 1991:5 ).

\section{Pementasan Topeng Pajegan adalah} seni pertunjukan yang cukup lama berkembang dan sampai saat ini masih sangat digemari oleh kalangan masyarakat Bali. Topeng adalah suatu benda yang menutup muka, jadi disamping Tapel, makeup bisa juga disebut Topeng. Kata Topeng berasal dan kata "tup" yang berarti tutup, kemudian mengalami formatif form, maka kata "tup" ditambah saja dengan kata "eng" menjadi Tupeng, akhimya menjadi Topeng. Jadi topeng digunakan untuk menyebutkan seni pertunjukan yang semua penarinya memakai Topeng atau tapel. Jenis-jenis topeng antara lain : Topeng Berutuk, Topeng Barong dan Calonarang, Topeng Sanghyang Legong, Topeng Telek dan Jauk, Topeng Wayang Wong Ramayana dan Parwa, 
Topeng Babad. Topeng Babad terdiri dari dua jenis yaitu Topeng Pajegan dan Topeng Panca, keduanya merupakan dramatari yang menggunakan babad sebagai sumber lakon (Bandem dkk, 1995:1-2)

Pementasan Topeng Pajegan merupakan salah satu bentuk tari yang mencerminkan nilai nilai spiritual dan watak kepahlawanan, yang sampai saat ini masih tetap eksis dan dilestarikan oleh masyarakat Bali. Pementasan Topeng Pajegan adalah merupakan salah satu seni budaya yang masih hidup di Bali, di dalam terpaduanya unsur-unsur seni itu, maka unsur seni tari yang paling dominan. Karena seni tari itu tidak lepas dari kehidupan masyarakat Hindu di Bali, yang selalu mempunyai keterkaitan dengan pelaksanaan upacara-upacara keagamaan. Banyak jenis-jenis topeng yang dipergunakan oleh penari Topeng Pajegan adalah satu di antaranya yang mutlak harus ada yaitu Topeng Sidakarya. Mendengar nama dari Topeng ini maka ialah yang menentukan Sidha-nya (berhasilnya) karya (upacara) dan tanpa kehadiran tokoh ini, upacara bisa dianggap belum selesai. Disamping itu sarana yang simbolik untuk Sidha-nya suatu yajna yang besar, yaitu diperlukan Panca Taru dan Catur Wija/beras yang berasal dari sebuah Pura yang bemama Pura Dalem Sidhakarya, disebelah selatan kota denpasar. (Bandem, 1976:12)
Keberadaan tari-tarian sakral tersebut yang memiliki daya tarik penonton baik dari kalangan anak-anak maupun dewasa adalah Pementasan Topeng Pajegan. Tari Topeng Pajegan disebut juga Tari Topeng Wali, karena ia berfungsi untuk upacara keagamaan dan dipentaskan sejajar dengan pertunjukan Wayang Gedog/Wayang Lemah (Wayang Upacara) serta dilakukan tepat pada waktu para sulinggih/Pandita menuntun upacara.

Pementasan Topeng Pajegan yang ada terkadang hanya berfungsi sebagai salah satu pelengkap dalam penyelenggaraan upacara keagamaan dalam tingkaatan tertentu. Padahal kalau ditingkatkan fungsinya akan mampu berfungsi sebagai salah satu media penerangan Agama Hindu. Mengingat belum maksimalnya peranan Tari topeng Pajegan sebagai salah satu media penerangan Agama Hindu, maka ada hal-hal yang harus dipahami oleh seorang penari Topeng Pajegan sehingga Pementasan Topeng Pajegan mampu ditingkatkan peranannya dalam fungsinya sebagai salah satu media penerangan Agama Hindu bagi umat Hindu pada khususnya dan umat lain pada umumnya.

\section{PEMBAHASAN}

Topeng Pajegan

Membicarakan tentang Pementasan Topeng Pajegan, maka unsur pertama yang 
mendasarinya adalah Tari Topeng secara umum. Di Bali ditemukan sebuah prasasti yang menyebutkan adanya pertunjukan Topeng yaitu pada prasasti Bebetin pada tahun 896 terdapat kata "Partapukan" yang artinya perkumpulan topeng atau pertunjukan topeng, yang antara lain berbunyi sebagai berikut:

"pande emas, pande besi, pande tembaga pemukul (juru tabuh bunyibunyian), pagending (biduan), Pabunjing (penari), parpadaha (juru gupek), pabangsi (juru rebab), partapukan (topeng-tapel), perbwayang (wayang), turun dipanglapuan di singhamandawa (dibuat oleh pegawai di singhamandawa) di bulan bekha ( bulan keX), hari pasaran wijayamanggala, tahun saka 818 (896 Masehi) yaitu pada waktu pemerintahan Raja Ugrasena di Bali. (Bandem 1976:3)"

Kata "Pajegan" adalah suatu istilah di dalam bahasa Bali yang berasal dari kata "pajeg" dan ditambah dengan sufik " $a n^{\prime}$ menjadi "pajegan" Yang berarti borongan. di dalam hubungannya dengan kata Topeng, maka yang dimaksud adalah seorang Penari Topeng memborong tapel dalam jumlah yang banyak untuk dipentaskan sendiri. la adalah "one man actor" memborong semua tugas dan peranan dalam pertunjukan dramatari Topeng itu. Pementasan Topeng Pajegan disebut juga Topeng Wali, karena ia berfungsi untuk upacara keagamaan dan dipentaskan sejajar dengan pertunjukan Wayang Gedog/Wayang Lemah (Wayang Upacara) serta dilakukan tepat pada waktu para sulinggih/Pandita melakukan Upacara.

Pementasan Topeng Pajegan dalam tulisan ini adalah bagaimana Topeng Pajegan mempunyai peranan sebagai media penerangan agama Hindu. Tidaklah mudah memberikan penerangan pada masyarakat soal agama. Pesan bisa saja disampaikan, namun bagaimana agar pesan itu merasuk dalam pikiran pendengarnya dan dipraktikkan dalam kehidupan sehari-hari, adalah merupakan salah satu tugas dalam peranannya pementasan Topeng Pajegan untuk menyampaikan berbagai pesan-pesan keagamaan.

Memberikan penerangan agama lewat Pementasan Topeng Pajegan diupayakan penonton tidak sekedar tertarik untuk melihat karena kostum penari yang digunakan atau tokoh yang diperankan, Tetapi lewat media Topeng Pajegan, tanpa disadari, mereka akan tertarik dengan apa yang disampaikan dengan alur cerita, berbagai humor dan menyelipkan ajaran agama yang menjadi tujuan penerangan Agama Hindu. Masyarakat merasa terhibur tanpa merasa dijejali dengan pesan-pesan sehingga mereka dapat menikmati hiburan 
sekaligus mendapat pencerahan. perubahan yang dirasa perlu sesuai dengan Pementasan Topeng Pajegan sebagai tontonan yang merupakan tari wali bisa juga menjadi tuntunan bagi umat Hindu. Kebijakan para seniman Tari Topeng Pajegan sangat dituntut, tidak sekedar membuat lelucon, sehingga penonton terpingkalpingkal ketawa namun tidak ada isinya. Nilai penting dan utama adalah bagaimana seniman Tari Topeng Pajegan menyelipkan ajaran Agama Hindu lewat media itu sehingga akan menyentuh hati para penonton.

\section{Bentuk Pementasan Topeng Pajegan}

Dalam Kamus Besar Bahasa Indonesia menyebutkan bahwa kata bentuk dapat diartikan bangun, sistem, susunan, rupa, wujud yang ditampilkan dan penggolongan bagi benda-benda yang berlekuk. Terkait dengan bentuk ialah mengandung arti wujud yang ditampilkan, sistem dan susunan (struktural) pementasan Tari Topeng Pajegan.

Keberadaan Penari dalam pertunjukkan Tari Topeng Pajegan, hampir sama peranannya seperti seorang dalang karena pada pertunjukannya harus mengatur sendiri topeng yang akan digunakan dan cerita yang akan dibawakan walau tidak pernah disebut sebagai Pencipta, namun tanpa disadari Penari Topeng Pajegan telah melakukan beberapa

kebutuhan pentasnya juga disebabkan oleh semangat dan nafas lingkungannya.

Penari Topeng pajegan pun sebenamya bisa dikatakan sebagai pujangga yang mempunyai hak untuk merubah, menambah dan mengurangi bagian tertentu dari pada sebuah cerita. Oleh sebab itu perubahan yang teijadi dengan sendirinya mudah diterima dan sejalan dengan trend yang ada sehingga tanpa hambatan diterima oleh masyarakat baik dari kalangan tua, remaja dan anak-anak. Dalam bentuk tampilan pementasan Tari Topeng Pajegan, berkaitan langsung dengan cara pengemasan dan cara penyajiannya kepada masyarakat. Dalam hal ini Tari Topeng Pajegan memiliki bentuk pementasan yang berbeda-beda sesuai dengan lakon yang dibawakan oleh Penari Topeng Pajegan itu sendiri.

Dalam buku yang berjudul Perkembangan Topeng-Bali sebagai Seni Pertunjukan yang ditulis oleh I Made Bandem M.A dan I Nyoman Rembang (1976:12-13 ), Kata "pajegan" adalah suatu istilah didalam bahasa Bali yang berasal dari kata "pajeg" dan ditambah dengan sufik "an" menjadi "pajegan" yang berarti borongan.

Dalam hubungannya dengan kata Topeng, maka yang dimaksud Pementasan Topeng Pajegan dalam tulisan ini adalah seorang penari Topeng mementaskan tarian 
Topeng dalam jumlah yang banyak dengan berbagai karakter penokohan. la adalah One Man Actor, yang menari dalam pertunjukan Topeng Pajegan.

Topeng Pajegan disebut juga Topeng Wali, Karena berfungsi untuk upacara keagamaan dan dipentaskan sejajar dengan Wayang Lemah (wayang upacara ) serta dipentaskan tepat pada waktu para sulinggih ( penghulu Agama ) melakukan upacara.

Dari sekian banyak topeng yang dipergunakan oleh penari Topeng Pajegan ada satu topeng yang mutlak harus dipentaskan yaitu Topeng Sida Karya. Mendengar nama dari topeng ini maka ialah salah satu yang menentukan Sidha- nya (berhasilnya) Karya ( upacara ) yang diselenggarakan, dan dipercaya tanpa kehadiran tokoh tersebut $\mathrm{Aa} / \mathrm{ya} / \mathrm{upacara}$ bisa dianggap belum selesai.

Sarana lain yang merupakan simbolis untuk Sidhanya suatu Karya yang besar, yaitu sebuah banten Tebasan Sidhakarya yang berasnya berasal dari sebuah desa atau pesubakan yang benama Sidhakarya, disebelah selatan kota Denpasar. dan tempat ini diduga adalah tempat kerajaan Kesari Warmadewa pada abad ke 8. Adapun cerita singkat terjadinya Topeng Sidakarya sebagai yang termuat dalam Babad sidhakarya adalah sebagi berikut:

Pada masa pemerintahan Dalem Waturenggong di Kerajaan Gel-gel, ketika beliau mengadakan upacara Eka Dasaludra dan nangluk merana di Pura Besakih datanglah seorang Brahmana dari Keling. Beliau mencari saudaranya di Bali dan yang diakui saudara adalah Dalem Waturenggong sendiri. Sudah barang tentu brahmana ini dianggap gila oleh para pengayah karena melihat ada orang dengan wajah jelek berpakaian compang-camping mengaku saudara Dalem dan segera diusirlah orang yang mengaku brahmana dari keling itu.

Namun karena merasa dihina dan dikecewakan maka brahmana keling pergi dari tempat itu namun sebelum pergi brahmana keling mengutuk agar rakyat diserang gering sejagat pulau Bali. Kemudian tidak selang berapa lama setelah kutukan itu diucapkan maka keadaan Bali benar demikian hingga karya tidak bisa dilaksanakan karena pengayah semua sakit dan tanaman-tanaman tidak mau berbuah dan berguguran.

Atas petunjuk sunya dari Ida Sanghyang Widhi maka diutuslah para Patih oleh Dalem untuk mencari Brahmana Keling tersebut di Bandana negara dan segera di hadapkan menghadap Dalem di Besakih. Dalem memohon kepada brahmana agar bisa mencabut kutukan itu dan karya Eka Dosa Ludra dan Nangluk Mrana dapat diselenggarakan.

Dalem pun beijanji apabila berhasil Dalem akan mengakui Brahmana keling 
sebagai saudaranya dan akan diberikan gelar Dalem Sidhakarya. Kemudian brahmana keling meminta saksi pituhu yang membenarkan segala yang diucapkannya. Ayam ini putih dan benar- benarlah ayam itu menjadi putih. Pohon kelapa ini berbuah dan benarlah berbuah, sehingga karya bisa dilaksanakan.

Akhimya Dalem waturenggong menepati janji beliau dan mengangkat saudara dan memberi gelar Dalem Sidhakarya kepada sang Brahmano Keling. Selanjutnya Dalem Sidhakarya mengaku sebagai Dewa segala merana ( tikus, walang sangit dan lain-lainnya).

Dalem menitahkan pula untuk sidhanya setiap upacara /upakara di bali agar memohon jatu karya ke Pura Dalem Sidhakarya yang berupa Catur Wija dan Panca Taru dan dinasehatkan pula agar rakyat jangan memaki hama/mrana. Demikianlah sejarah singkat teijadinya Topeng Sidhakarya yang termuat dalam Iontar Bebali Sidhakarya

\section{Fungsi Pementasan Topeng Pajegan}

Dalam Kamus Lengkap Bahasa Indonesia, kata fungsi mengandung arti kenyataan suatu hal, daya gima, jabatan (pekeijaan) yang dilakukan. Fungsi dapat diartikan kegunaan dan daya guna estetika Pementasan Topeng Pajegan. Agama Hindu adalah sumber utama yang menjiwai nilai- nilai kebudayaan Bali. Kesenian merupakan produk budaya tidak terlepas dari ikatan nilai-nilai luhur budaya Bali terutama nilainilai estetika yang bersumber dari agama Hindu.

Dalam kebudayaan Bali hingga kini bentuk-bentuk kesenian wali dan bebali masih dipertahankan sebagai kesenian sakral untuk upacara keagamaan, sedangkan bentuk-bentuk kesenian balih-balihan diperlukan sebagai kesenian sekuler yang bisa dipentaskan sewaktu- waktu untuk publik (Dibia, 2000 : 11).

Hasil-hasil lokakarya Topeng (1975: 23-4) yang termuat dalam kertas keija Listibia Daerah Tingkat II Gianyar dengan judul " Topeng Sebagai Salah Satu Bentuk Theater" Tari Topeng Pajegan disajikan sebagai runtutan wali ( Bebali), yaitu untuk melengkapi Upakara suatu Upacara (Yadnya), Dewa Yadnya dan atau Pitara Yadnya lanjutan (Ngasti, mukur dan sebagainya). Tanpa kehadiran topeng Pajegan pada Yadnya tersebut, atau pada suatu yadnya tertentu maka dianggap yadnya itu belum selesai. Disini juga dinyatakan Tata busana topeng Pajegan tidak mengalami perubahan kecuali Topeng yang dipergunakan.

Bali Post (9 April 2006:11) dengan judul "Upaya Mengajegkan Topeng Pajegan". Menyatakan sesuai dengan fungsinya Topeng Sidhakaiya yang 
merupakan rangkaian dari Tari Topeng Pajegan adalah memberikan pengukuhan terhadap kesuksesan sebuah upacara yang bertalian dengan unsur kesucian.

Sedangkan dalam konteks seni Topeng Pajegan mampu memberikan wawasan moral- spiritual. Dan sebagai pengukuh upacara keagamaan, sudah semestinya para seniman topeng memberikan persembahan seni dan mempersembahkan keindahan sukmawi bagi masyarakat pendukungnya.

Dalam buku yang berjudul Perkembangan Topeng-Bali sebagai Seni Pertunjukan yang ditulis oleh I Made Bandem M.A dan I Nyoman Rembang( 1976:12-13 ) Topeng Pajegan disebut juga Topeng Wali, Karena berfungsi untuk upacara keagamaan dan dipentaskan sejajar dengan Wayang Lemah (wayang upacara ) serta dipentarkan tepat pada waktu para sulinggih ( penghulu Agama ) melakukan upacara.

Dalam tulisan ini yang saya maksud Pementasan Topeng Pajegan Sebagai Media Penerangan Agama Hindú adalah bahwa dalam pementasannya Penari Topeng Pajegan adalah membawa misi untuk menyampaikan Ajaran Agama Hindú, karena Pementasan Topeng Pajegan secara maksimal bisa berfungsi sebagai media tersebut di bawah ini:

\section{Media Komunikasi dan Informasi}

Salah satu dari fungsi Pementasan Topeng Pajegan adalah sebagai media komunikasi yang dapat memperkuat keyakinan umat Hindú terhadap nilai-nilai maupun norma-norma yang terkandung dalam ajaran Agama Hindú. Sebagai media Komunikasi dalam pementasan Topeng Pajegan biasanya disisipkan berbagai pesan untuk mengajak masyarakat berpartisipasi dalam bidang pembangunan, bidang kesehatan, kebersihan serta pemahaman tentang sarana- sarana dalam upacara yadnya dan penggalian dana, di sini peranan Penari Topeng Pajegan sangat penting karena Penari sebagai sentral dalam pertunjukan Topeng Pajegan maka Penari menentukan sukses tidaknya pertunjukan dan berhasil tidaknya visi dan misi yang dibawanya.

Sebagai media masa tradisional pertunjukan Topeng Pajegan dijadikan sebagai salah satu media informasi karena dari segi penampilan sangat komunikatif dalam masyarakat. Sedikitnya dapat dipakai untuk memahami salah satu dari tradisi dan salah satu cara pendekatan terhadap kehidupan serta permasalahannya.

Dengan munculnya media masa TV juga sebagai bukti kesenian tradisonal seperti Tari Topeng Pajegan dan seni tari yang lainnya tidak mengisolasi diri, hal ini dilihat adanya pertunjukan berbagai bentuk 
kesenian, baik direkam, di dalam studio, maupun di luar studio, sebagai hasil integrasi kesenian tradisional dengan teknologi modern dan hasilnya pun dapat diterima di masyarakat.

\section{Media Hiburan}

Orientasi Pementasan Topeng Pajegan disamping sebagai pemuput yajna adalah penonton, karena dengan adanya penonton misi yang ingin disampaikan akan terlaksana disamping secara psikologi antara Topeng dengan penari mempunyai hubungan batin saling membutuhkan, begitu juga pementasan Topeng Pajegan membutuhkan dukungan dari penonton, dan sebaliknya Penonton membutuhkan objek yang ingin ditontonnya. Untuk memenuhi kebutuhan itu Pementasan Topeng Pajegan hams mampu mengubah emosi penonton dalam berbagai kondisi seperti halnya rasa sedih, gembira, benci, bahkan menyebalkan dengan sistem komunikasi yang tepat yang artinya pementasan Topeng Pajegan hams mampu mengikat perhatian penonton. Garapannya tidak membosankan termasuk perannya memiliki teknik yang menawan humomya segar dan bermanfaat.

Manusia dalam kehidupannya mempunyai dua kebutuhan antara lain kebutuhan jasmaniah dan rohaniah. Kebutuhan jasmaniah yang pertama yaitu bempa makanan dan kebutuhan jasmaniah (sekunder). Kedua kebutuhan yang membuat lebih nikmat. Adapun kebutuhan rohaniah salah satunya ialah hiburan. Untuk memenuhi kebutuhan dalam hal ini Pementasan Topeng Pajegan berfimgsi sebagai tontonan atau hiburan dan tuntunan (nilai atau pesan), sebagai seni pergaulan dan dapat pula sebagai kegiatan seni. Sebagai media hiburan Pementasan Topeng Pajegan merupakan salah satu dari kesenian yang dapat memenuhi kebutuhan hati orang yang menyaksikan, menimbulkan rasa puas yang mendalam. Untuk sampai pada hal tersebut diperlukan pengertian dan kemampuan untuk mencemanya secara mendalam.

\section{Fungsi Kritik Sosial}

Hubungan antara karya seni dengan kritik sosial bukanlah suatu yang aneh, artinya karya-karya seni yang bermuatan kritik atau proses sosial bukanlah suatu yang bam. R.C. Kwant dalam bukunya "manusia dan kritik" antara lain mengemukakan bahwa kritik adalah sesuatu yang bemilai besar dan bahkan merupakan salah satu nilai dasar eksistensi kemanusiaan, serta kritik merupakan sumber dari segala keamajuan, artinya tidak ada kamjuan kalau menutup diri terhadap kritik. Sasaran kritik adalah kenyataan yang dihadapi. Jangan dibalik fomulasinya sehingga pernyataan bahwa 
segala kenyataan yang dihadapi adalah sasaran kritik.

Pada sisi lain Kwant mengatakan bahwa : Barang siapa melancarkan krtiik, tidak cukup baginya hanya mengetahui kenyataan yang dihadapinya. Sebab barang siapa melancarkan kritik, ia berusaha untuk menentukan apakah kenyataan yang dihadapinya itu benar-benar seperti apa yang seharusnya. Jadi ia harus pula mengetahui bagaimanakah sehamsnya yang perlu dinilai itu (...) kritik adalah penilaian atas kenyataan yang dihadapinya dalam sorotan norma.

Pernyataan di atas menisyaratkan bahwa siapapun yang melakukan kritik ia hams berada pada jalur norma. Artinya melakukan kritik bukanlah suatu yang tabu, tetapi tabu adalah melakukan kritk yang tidak dibingkai dengan norma- norma yang ada. Bukannya bahwa apa yang nyata diperbuat sesuai dengan norma.

Isyarat lain yang dapat dipetik dari kutipan di atas bahwa, barang siapa yang tidak mengetahui bagaimana prestasi manusia itu sehamsnya, serta tidak mengetahui pula secara sungguh-sungguh, maka secara normatif orang tersebut tidak layak melancarkan kritik (Ketut Cerata dalam Putu Yuniasih,2008: 55).

Kritik sosial sesungguhnya mempakan wacana kemasyarakatan yang diungkapkan oleh dalang inovatif di dalam pementasannya dan dipandang penuh dengan nuansa kritik. Melalui pementasanya dalam memiliki kemampuan, kesempatan dan kebebasan melancarkan krtiik untuk dapat dikonsumsi oleh penontonya. Dalam hal ini kritik sosial sangat bermanfaat dalam rangka perbaikan pola pemikiran, perkataan, dan perilaku masyarakat penonton.

\section{Makna Keagamaan dan Sosial Kemasyarakatan}

Keberadaan seni pertunjukan Topeng Pajegan nampaknya sulit dipisahkan dengan sistem keagamaan masyarakatnya. Karena pada umumnya pertunjukan Topeng Pajegan merupakan kelengkapan suatu proses ritual keagamaan. Agama Hindu mengenal lima bentuk uapacara yang disebut Panca Yadnya yaitu lima unsur pengabdian yang tulus ikhlas tanpa pamrih yang diwujudkan dalam bentuk upacara (ritual) dan perilaku (etika) yang terdirid dari Dewa Yadnya yaitu korban suci yang tulus ikhlas kepada Ida Sang Hyang Widhi Wasa beserta manifestasi- Nya dengan jalan sujud bakti dan mengikuti segala ajaran-ajaranNya.

Pitra Yadnya, yaitu suatu upacara untuk pemujaan dengan hati yang tulus ikhlas ditujukan kepada pitara (roh leluhur) melalui proses ngaben. Manusa Yadnya yaitu korban suci yang tulus ikhlas untuk keselamatan keturunan serta kesejahteraan 
umat manusia. Rsi yadnya yaitu korban suci yang tulus ikhlas untuk kesejahteraan para rsi atau pendeta. Bhuta Yadnya yaitu korban suci yang tulus ikhlas kepada makhluk bawahan untuk memelihara kesejahetraan dan ketentraman alam semesta (Team Penyusun Panca Yadnya, 2006 : 44).

Oleh karena itu pemakaian atau pemilihan lakon menjadi hal yang sangat penting dalam pertunjukan Topeng Pajegan. Karena sebagai media pengejewantahan makna dan simbol upacara. Sehingga kandungan cerita atau lakon yang menjadi pokok dari keterampilan lainnya, sebagai fimgsinya dari bagian upacara (Bandem dkk, 1976 : 15).

Dalam upacara keagamaan Tari Topeng Pajegan mempunyai fimgsi yang sangat penting didalam menerangkan arti dan makna sebuah upacara dengan bahasa yang mudah dimengerti dan dipahami oleh umat. Bagi masyarakat di Desa Pakraman Pujung Sari, yang masih memiliki tradisi yang kuat dalam berkesenian, seni pertunjukan Topeng Pajegan dianggap mempuyai arti dan makna yang penting dalam kehidupan sosial masyarakatnya karena kesenian dan agama bagaikan sisi mata uang yang tak dapat dipisahkan satu dengan lainnya (wawancara, 10 Januari 2009).

Dari bermacam-macam seni pertunjukan di Desa Pakraman Pujung Sari baik yang tergolong seni pertunjukan wali, bebali maupun balih-balihan di dalamnya tersimpan nilai- nilai agama, nilai logika, nilai estetika dan nilai etika. Pengelolaan nilainilai agama dalam seni pertunjukan Topeng Pajegan dapat direfleksikan melalui konsep Tri Hita Karana yaitu pandangan masyarakat tentang hakekat keseimbangan hidup antara manusia dengan Tuhan, manusia dengan manusia dan ksesimbangan hidup manusia dengan lingkungan, sehingga tercapai keharmonisan hidup bermasyarakat.

\section{Makna Spiritual}

Dalam kamus Besar Bahasa Indonesia kata spritual berasal dari kata sprit yang artinya semangat, jiwa atau roh, sukma dan spiritual berarti berhubungan dengan atau bersifat kejiwaan rohaniah dan batiniah. Topeng merupakan timan wajah tigadimensi yang banyak sekali menokohkan Dewa-dewa atau manusia-manusia sakti reikamasi Dewa. Di samping itu setelah topeng-topeng itu lengkap dibuatkan suatu upacara pamlaspasan agar topeng-topeng tadi menjadi topeng yang berjiwa.

Di dalam keseharian topeng-topeng tersebut berkumpul dalam satu katung yang dimana topeng-topeng tersebut selalu diupacarai, setidak-tidaknya dengan yadnya sesa atau banten saiban. Belum lagi setiap hari-hari baik dan hari- hari keramat seperti : pumama, tilem, buda wage, anggara kasih, kajeng kliwon, dan lain sebagainya. Topeng- 
topeng tersebut dibuatkan upacara yang lebih besar (Tunjung wawancara 10 Januari 2009 ).

Upacara tersebut akan mencapai puncaknya pada saat Saniscara Kliwon wuku Wayang yang dikenal dengan Tumpek Wayang. Karena itulah pada hari tersebut banten yang dibuat untuk mengupacarai topeng-topeng dan wayang itu adalah banten yang lebih besar dan tingkatannya lebih tinggi. Dalam hal ini tidak hanya topeng-topeng dan wayangnya saja yang dibuatkan upacara yang berupa banten melainkan dari penari Topeng Pajegan juga Dalang akan berpangkat menuju tempat pementasan juga harus dibuatkan banten. Bahkan saat di peijalanpun ketika melewati tempat-tempat yang kramat setidaktidaknya menghaturkan canang atau sesajen. Tidak hanya sampai di situ saja, dari mulai membuka katung (peti topeng) sampai pertunjukan berlangsung dibuatkan banten nuur, hingga saat dalang tiba di depan rumah tetap harus menghaturkan banten.

Topeng sesungguhnya memiliki misi untuk memberi bayangan kepada masyarakat bagaimana manusia-manusia mensyukuri anugrah Tuhan yang telah menciptakan alam semesta dengan segala isinya. Setidaknya dengan mewujudkan hal tersebut kita baru berkata, berpikir dan bertindak yang baik. pada konteks ini Topeng Pajegan banyak memberi makna guna untuk penjemihan jiwa, pembersihan batin, pengayaan rohani, pengagungan sukma yang berkaitan dengan spirit manusa dan secara nyata penuh mengaromakan nuansa spiritual. Hal itu dapat diyakini karena Penari Topeng Pajegan akan merasakan adanya sebuah getaran ketuhanan dalam kehidupannya. Kendatipun orang lain tidak mampu merasakan pada yang dirasakan oleh Penari Topeng, namun kesuksesan pertunjukan Topeng Pajegan ini dapat dijadikan indikator bahwa, Penari memperoleh semacam sprit dalam rangka melaksanakan tugas dan kewajibannya sebagai pengemban seni, harus memberikan apa yang mampu diberikan kepada masyarakat yang berkenan menyaksikan pementasan topeng pajegan tersebut. Dan dalam pementasan Topeng ini tidak hanya difiingsikan sebagai hiburan melainkan juga banyak menerangkan tentang ajaran-ajaran Agama Hindu.

\section{PENUTUP}

\section{Simpulan}

Berdasarkan uraian di atas ditarik kesimpulan sebagai berikut : bentuk pementasan Topeng Pajegan sesungguhnya selau berubah-ubah sesuai dengan lakon yang dibawakan oleh Penari sendiri. Dalam pandangan struktural suatu karya seni merupakan sebuah struktur yang masing- 
masing unsumya saling berkaitan satu dengan yang lainnya, dalam keseluruhan dan keutuhan yang kuat antara masing-masing unsur menjadi syarat dalam suatu seni pementasan termasuk seni petopengan, dengan kata lain setiap struktur memiliki kedudukan yang sangat penting. Sarana pementasan Topeng Pajegan bertumpu pada media yang tersedia. Seperti diketahui kekuatan dalam pementasan Topeng Pajegan terletak pada pengetahuan Penari Topeng Pajegan itu sendiri dan pengalamannya di dunia pentas.

Keberadaan pementasan Topeng Pajegan di Desa Pakraman Pujung Sari dengan sistem relegi kemasyarakatan khususnya bagi umat Hindu sangat sulit untuk punah karena merupakan kelengkapan dari ritual keagamaan. Dalam fungsinya sebagai kelengkapan ritual keagamaan pementasan Topeng Pajegan juga dapat difungsikan sebagai media komunikasi dan informasi dimana dalam setiap pementasan biasanya disisipkan berbagai pesan untuk mengajak masyarakat berpartisifasi dalam segala bidang seperti misalnya bidang pembangunan, bidang kesehatan, kebersihan, pemahaman tentang sarana dalam upacara yadnya serta bidang pengalian dana. Selain itu juga dapat berfimgsi sebagai media hiburan dimana pementasan Topeng Pajegan ini dapat berfimgsi sebagai tontonan atau hiburan sekaligus tuntunan, sehingga dalam setiap pementasan Penari mampu menggugah emosi penonton dalam berbagai kondisi, agar pementasannya tidak membosankan dan memiliki sedikit humor yang segar dan bermanfaat. Sebagai fiingsi kritik sosial dimana dalam hal ini hubungan antara karya seni dengan kritik sosial bukanlah suatu yang aneh, melainkan karya-karya seni yang bermuatan kritik atau protes sosial perlu dikritisi dan diprotes sesuai dengan kenyataan yang ada dan sedang berkembang di masyarakat. Makna yang terkandung dalam pementasan Topeng Pajegan adalah makna keagamaan dan sosial kemasyarakatan dan makna spiritual.

Jadi Pementasan Topeng Pajegan sebagai Media Penerangan Agama Hindu akan dapat difimgsikan dengan baik apabila Penari Topeng Pajegan mampu menguasai berbagai materi yang berkaitan dengan Ajaran Agama Hindu dan juga peka terhadap situasi lingkungan sosial dimana pementasan tersebut dilaksanakan sehingga mampu meningkatkan Sradha dan Bhakti Umat Hindu di Desa Pakraman Pujung Sari khususnya dan umat Hindu Bali pada umumnya.

\section{DAFTAR PUSTAKA}

Anggoro, Toha, 2007. Metoda Penelitian. Jakarta : Universitas Terbuka. Armada, I Nyoman, 1984, Tari Topeng 
Pajegan Di Desa Mengwi. Akademi Seni Tari Indonesia (ASTI) Denpasar.

Asmara, Andhy. 1978, Apresiasi Drama.

Bandung: Penerbit Percetakan Timbul.

Awig-Awig Desa Pakraman Pujung Sari

Tahun 2000.

Babad Sidakarya, 2003, Upada Sastra -

Denpasar.

Bali Post 2006, Upaya Mengajegkan Topeng

Pajegan.

Bandem, I Made dan Rembang, I Nyoman, 1976, Perkembangan Topeng Bali Sebagai Seni Pertunjukan. Denpasar. Proyek Penggalian Pembinaan, Pengembangan Seni Klasik/Tradisional dan Kesenian Barn, Pemda Bali.

Bandem, I Made, 1983, Inseklopedi Tari Bali, Denpasar: Akademi Seni Tari Indonesia (ASTI).

Bandem, I Made, 1996, Heroisme Dalam

Sastra Babad Di Bali. Sebagaimana yang tampak pada seni Pertunjukan Topeng. Makalah sarasehan sastra Daerah Bali pada PKB XVII. Denpasar: Panitia Seminar.

Bandem 1996, Etnologi Tari Bali. Yogyakarta: Kanisius.

Ketut Cerata dalam Putu Yuniasih,2008, Pementasan Wayang Cenk Blonk sebagai Media Penerangan Agama Hindu.

Dibia, I Wayan, 1993, Seni Pertunjukan dan
Sumbangannya dalam Pern binaan Kepribadian Bangsa, dalam Kebudayaan dan kepribdian Bangsa. Editor Tjok Rai Sudaría. Denpasar, Upada Sastra.

Dibia, I Wayan, 2000, Pluralisme Budaya Sebagai Potensi Indonesia Barn Dalam Majalah Mudra no.I 1 Tahun IX 2000. Denpasar STSI.

Dibia, I Wayan, 2002, Teori Estetika Indonesia. Bahan Kuliah Program Doktor (S3) Kajian Budaya.

Djelantik, A.A. Made, 1990, Estetika Instrumen. Denpasar. Sekolah Tinggi Seni Indonesia.

Djelantik, A.A. Made, 1999, Estetika Sebuah Pengantar. Bandung: Masyarakat Seni Pertunjukan Indonesia. Ensiklopedi Indonesia 1,1991.

Granoka, Ida Wayan Oka, 1998, Memori Bajra Sandhi, Perburuan Ke Prana Jiwa. Perburuan Seorang Ida Wayan Granoka. Denpasar: Sanggar Bajra Sandhi bekeija sama dengan PT Seraya Bali Style.

Hartoko, Dick, 1986, Manusia Dan Seni. Yogyakarta: Kanisius.

Hasil-Hasil Lokakarya Topeng, 1975 Topeng Sebagai Salah Satu Bentuk Teater. H Malik, 1994, Pemanfaatan Media Dalam Menunjang Kemahiran Menulis Bahasa Arab. Universitas Negeri Malang. 
Kantun, I Nyoman dan Yadnya, I Ketut, 2003, Babad Sidakarya. Denpasar: Upada Sastra, 2003.

Kardji, I Wayan, 1992, Topeng Prembon Bali dan Lakon.

Kardji, I Wayan, 2001, Topeng Prembon Leluhur Orang Bali. Denpasar: CV. Bali Media. Koentjaraningrat, 1990JPengantar Imu Antropologo Jakarta: RinikaCipta.

Mantra, 1991, Landasan Kebudayaan Bali. Denpasar : Yayasan Dharma Sastra.

Marajaya, Made. 2002. Pertunjukan Wayang Kulit Parwa Lakon Brahmana Sidi di TVRJ Denpasar. Kajian Budaya UNUD Denpasar.

Murgianto, 1993:4 .Seni Pertunjukan Bali

Ngurah, I Gusti Made dkk,1999, Buku

Pendidikan Agama Hindu untuk Perguruan Tinggi. Paramita Surabaya. Sedyawati, Edi 1981, Pertumbuhan Seni Pertunjukan. Jakarta: Sinar Harapan. Sueka, I Gst. Ngr, 1994, Peranan Penasar Dalam Petopengan. Sekolah Tinggi Seni Indonesia (ASTI) Denpasar. Sukraka, I Gde, 1994, Fungsi Tari Topeng Monyer Pada Pertunjukan Topeng Pugra di Tegalkuwalon. Sekolah Tinggi Seni Indonesia (ASTI) Denpasar.

Wicaksana, Dewa Ketut. 2004.

Astadasaparxva dana Kekawin Bharatayuda sebagai Sumber Lakon Wayang Kulit Parwa di Bali Dalam
Jurnal IImiah Pewayangan Volume. 3. No. 1 September 2004.

Zoetmulder, P J.1985, Sastra Jawa Kuno, Selayang Pandang. Jakarta: Djembatan. 